\title{
Detection of subsidence in the Ebro Delta plain using DInSAR: analysis of the measurements and the factors that control the phenomenon
}

\author{
Xavier Rodriguez-Lloveras ${ }^{1,4}$, Miquel Vilà ${ }^{2,4}$, Oscar Mora ${ }^{3,4}$, Fernando Pérez ${ }^{3}$, Roser $\mathbf{P i}^{2,4}$, and \\ Jordi Marturià ${ }^{1,4}$ \\ ${ }^{1}$ Geohazards Unit, Institut Cartogràfic i Geològic de Catalunya (ICGC), Barcelona, 08038, Spain \\ ${ }^{2}$ Urban Geology, Geophysics Division, ICGC, Barcelona, 08038, Spain \\ ${ }^{3}$ Photogrammetry and Remote Sensing Development Unit, ICGC, Barcelona, 08038, Spain \\ ${ }^{4}$ Active Geological Processes and Geohazards Research Group, ICGC, Barcelona, 08038, Spain
}

Correspondence: Xavier Rodriguez-Lloveras (xavier@rodriguez-lloveras.com.es)

Published: 22 April 2020

\begin{abstract}
The Ebro Delta is a highly vulnerable Mediterranean coastal ecosystems located on the northern Mediterranean coast of Spain. Determining its subsidence rate and sources is a key issue for the present and future management of this area. Differential Interferometry Synthetic Aperture Radar (DInSAR) compared with the contribution to subsidence of the compaction of delta's sediments and the lithosphere's deformation, indicated a general Ebro Delta subsidence ranging from $<1$ to $\sim 2.3 \mathrm{~mm} \mathrm{yr}^{-1}$. Subsidence is determined to be mainly driven by natural sediment compaction $(\sim 76 \%)$, with areas strongly influenced by local processes associated to their sedimentary distribution and composition, or external factors such as sea level rise.
\end{abstract}

\section{Introduction}

Ebro Delta is one of the modern delta plains formed during the Holocene, which can be found in a variety of geographic and geologic settings on coastal margins worldwide (Stanley and Warne, 1997; Ibáñez et al., 2019). The formation of these delta plains is a consequence of a marked deceleration in sea-level rise started at $\sim 8000 \mathrm{yr} \mathrm{BP}$ following the end of the last glacial period (Doyle et al., 2015; Siddall et al., 2003). The modern river delta plains are areas very susceptible to flooding as a result of their low elevation. Human activities, especially since the beginning of the nineteenth century and its Industrial Revolution, may have a deep impact on delta's flooding hazard (Syvitski et al., 2009). As a consequence of the negative aggradation-sinking balance, most of the world's major river deltas are sinking relative to their local sea level. Different climate change scenarios agree on a consistent sea level rise in areas like the northern Mediterranean coast of Spain, where Ebro delta is located (Church and White, 2011; Jevrejeva et al., 2012). As a consequence of its low aggradation ratio versus subsidence and eustatic sea-level rise (Ibáñez et al., 2014), some Ebro Delta plain areas are already below sea level and up to $40 \%$ of its area is less than $50 \mathrm{~cm}$ above it (Fig. 1). For these reasons Ebro Delta is considered one of the most vulnerable Mediterranean coastal ecosystems to the effects of climate change (Fatoric and Chelleri, 2012; Giosan et al., 2014), and make determining the subsidence rate and sources a key issue for the present and future management of this area.

Subsidence in delta plains, understood as a negative aggradation-sinking balance, is a complex phenomenon involving many interwoven natural processes including crustal motion, climate, vegetation dynamics, availability of sediment from the watershed, the mechanical, biological and chemical compaction of sediment, and the marine sedimentary drifts (Maldonado, 1972). Apart from these natural processes, the anthropic activity such as subsurface mining or the interception of upstream river-borne sediment by dams, can exceed natural compaction by an order of magnitude (Syvitski et al., 2009) or generate a drastic decrease in the sediment contribution to the deltaic systems, respectively (Ibáñez et al., 2014). Furthermore, the use of artificial levees 


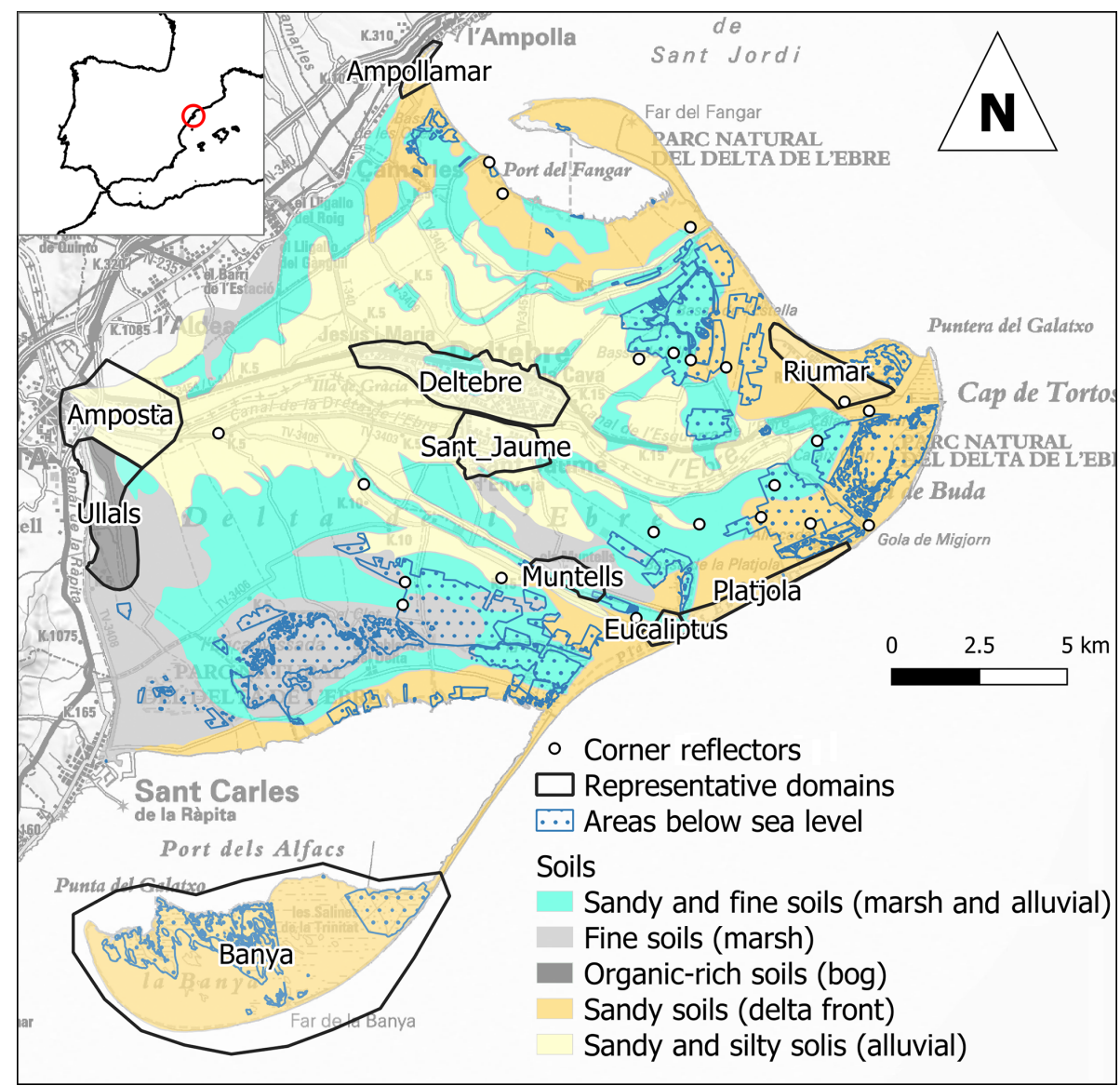

Figure 1. Map of the Ebro delta plain including soils distribution derived from the Soil map of Catalonia $1: 25000$ (deposit type in parenthesis), corner reflectors location, selected domains and areas below the sea level. This figure uses a proprietary @ ICGC base map.

combined with reductions in the number of distributary channels can prevent river flooding onto the delta plain (Ibáñez et al., 2014). As a consequence of all the factors involved, determination of the modern delta plains subsidence rates is a topic of increased complexity. Different types of sensors allow point measurements of subsidence and/or sedimentation rates with high local precision. However, each method can resolve only certain local and temporarily-restricted pieces of delta surface elevation change (Higgins, 2016). Given the spatial complexity of movements on deltaic systems, local information is insufficient to determine the general delta plain dynamics, making thus necessary the use of measuring techniques able to cover extended areas with good general resolution. For this reason, in this study, subsidence is analysed trough differential interferometry SAR (DInSAR) data, whose availability covers the last 26 years in two time periods (1992-2010 and 2014-2018, respectively).

The purpose of the present study is to determine presentday subsidence susceptibility of the Ebro Delta plain, in order to improve this phenomenon understanding and influence on the aggradation-sinking balance.

\section{Methodology}

Subsidence rate was measured through Differential Interferometry Synthetic Aperture Radar (DInSAR) techniques using satellite data obtained from European Space Agency (ESA) missions (Mora et al., 2018). DInSAR is a remote sensing technique that uses a stack of satellite images to monitor the surface motion with millimetric accuracy. These Synthetic Aperture Radar (SAR) satellite images are captured in the microwave domain. This remote sensing technique allows obtaining subsidence maps for large areas, with a great amount of measurement points and without field work. The SAR signal, which is used to measure surface motion, can be affected by several error/noise sources: (1) Atmospheric artefacts: disturbance of the microwave signal travelling from the satellite to the ground that adds noise to the measurement. (2) Thermal noise: Electrical fluctuations arising from the random thermal motion of electrons in the electronic devices composing the radar transmitter and receiver. (3) Topographic error: imperfections on the Digital Elevation Model (DEM) used to remove the topographic component of the signal backscattered to the radar. If these components are cor- 
rectly removed we can isolate the Ground motion: component which provides information about the surface motion during the observation period. In this study a ICGC's developed methodology to separate the ground motion component from the rest of non-desired components has been used. This methodology allows to process large quantities of DInSAR images, obtaining a high density of measurement points (depending on the land cover) no matter their non-linear motion behaviour. The processor is divided into the following parts: (1) Classical DInSAR: In this first step the stack of images is co-registered to a single master acquisition's geometry and interferograms are generated. These interferograms are created by comparing radar signal from different pairs of images, their signal components described above. (2) Advanced DInSAR: This part of the processor is known as Persistent Scatterer Interferometry (PSI), and tries to separate the different components of the interferometric signal, obtaining the final ground motion measurement. Nevertheless, one of the main drawbacks of this processing technique is that require low variation rates on surface content during the analysis period in order to obtain high quality measurements (interferometry coherence). As a consequence, soil covers experimenting great variations along the year, as it happens in vegetated and agricultural areas, return poor coherence. This limitation is critical in Ebro Delta plain since extremely good signal quality is necessary as subsidence rates are on the verge of the technique sensitivity. Around $65 \%$ of Ebro Delta emerged plain is covered by crops. Hence its cover is highly variable during the year. In order to overcome this drawback, a total of 22 high response corner reflectors were installed in areas were poor coherence was expected (Fig. 1). In addition, surface information was restricted to domains representative of the different delta environments with higher coherence in all the considered intervals, to correlate the DInSAR data with subsidence sources (Fig. 1).

Subsidence sources are estimated trough the Syvitski et al. (2009) formula without the eustatic sea-level rate, as subsidence $(\Delta S)$ is independent of this parameter:

$\Delta S=A-C_{\mathrm{N}}-C_{\mathrm{A}} \pm M$,

where $A$ is aggradation, $C_{\mathrm{N}}$ natural compaction, $C_{\mathrm{A}}$ Artificial compaction and $M$ deformation of the lithosphere.

Based on Ibáñez et al. (1997), River aggradation at the Ebro delta can be considered null. Natural compaction is determined through the Holocene deposit thickness determined by Benjumea et al. (2017), the surface sedimentary pattern and the Meckel et al. (2007) delta plain deposits compaction rate model. Compaction rates are considered for an accumulation interval of 8000 years and compaction percentiles $P_{10}$ and $P_{90}$, over the selected domains. Artificial compaction is calculated trough the relative movements within domains. Finally deformation of the lithosphere is determined as a combination of flexural effect and tilting of the continental platform margin. These values are calculated based on
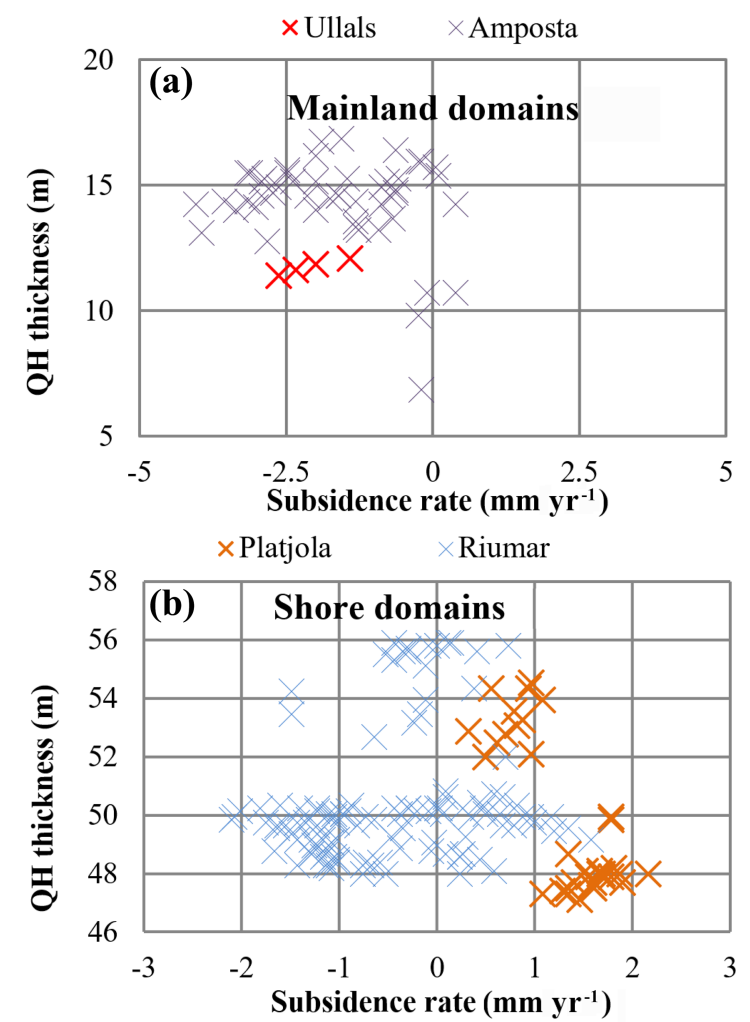

Figure 2. Comparison between sediment thickness of the Ebro delta plain and subsidence rate measured with DInSAR in Mainland (a) and Shore (b) Domains.

the water-sediment dynamic load since the last glacial maximum, based on the sea level changes from Miller (2013) dataset and the sediment thickness accumulation determined on Ebro delta by Mauffrey et al. (2017) as developed in Rodriguez-Lloveras et al. (2018).

\section{Results}

The obtained DInSAR results show subsidence movements ranging from $<1$ to $\sim 17 \mathrm{~mm}$ with an average subsidence rate of $0.78 \mathrm{~mm} \mathrm{yr}^{-1}$, a standard deviation of $0.89 \mathrm{~mm} \mathrm{yr}^{-1}$ and a maximum of $4.04 \mathrm{~mm} \mathrm{yr}^{-1}$, located in the domains with lower sedimentary thickness and closer to the main land (Fig. 2a). As a contraposition of subsidence, a vertical accretion up to $2.14 \mathrm{~mm} \mathrm{yr}^{-1}$ has been observed, which is mainly located on some of the shore domains with higher sedimentary thickness (Fig. 2b). Despite these extreme values, the general trend shows proportionality between sedimentary thickness and subsidence (Fig. 3). Considering the subsidence sources, data do not show significant movement distribution changes inside the domains. As there is no exploitation of resources in Ebro delta subsoil, the artificial compaction in Ebro delta plain is considered null. The Holocene sedimentary prism of the Ebro delta plain is up to $55 \mathrm{~m}$ thick. For these thicknesses, Meckel (2007) model of natural com- 

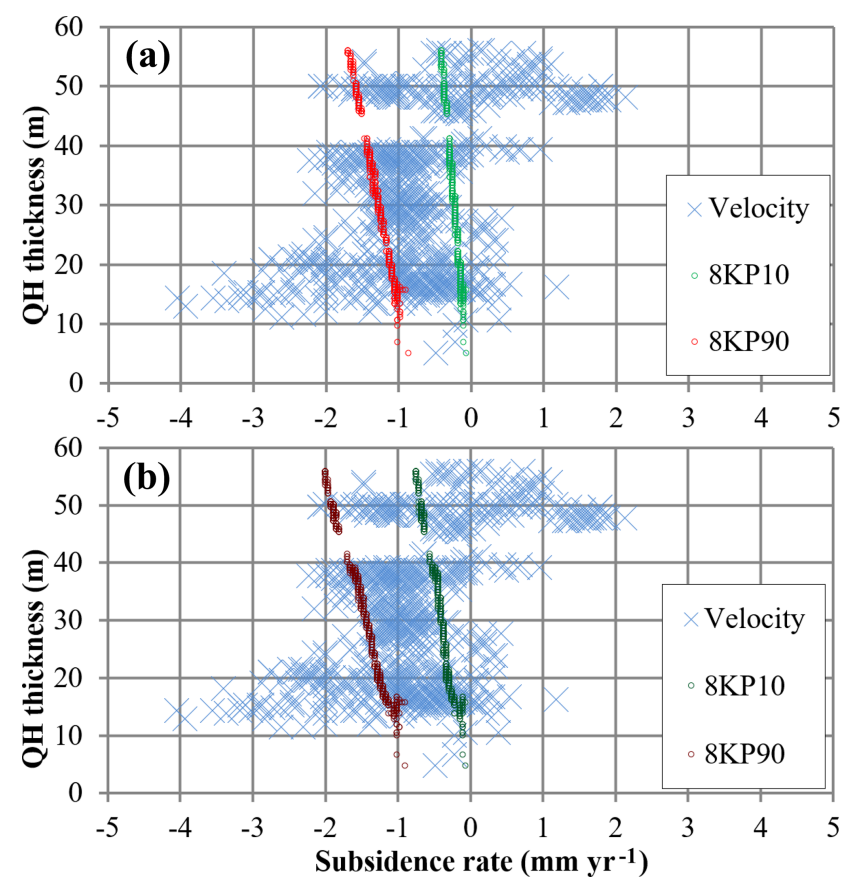

Figure 3. Comparison between subsidence rates on Ebro delta with DInSAR results, considering only the natural compaction (a) and adding the lithospheric efects (b).

paction rates show values from 0 to $0.4 \mathrm{~mm} \mathrm{yr}^{-1}$ for percentile $P_{10}$ and from 0.8 to $1.7 \mathrm{~mm} \mathrm{yr}^{-1}$ for percentile $P_{90}$. These results follow the general trend of the DInSAR measured movement, which mainly fall between the percentiles $P_{10}$ and $P_{90}$ compaction rates, being closer to percentile $P_{90}$ (Fig. 3a). The inclusion of flexural effect and tilting contributions to total subsidence increase the subsidence rate up to $0.41 \mathrm{~mm} \mathrm{yr}^{-1}$, being up to $0.29 \mathrm{~mm} \mathrm{yr}^{-1}$ consequence of the flexural effect and up to $0.12 \mathrm{~mm} \mathrm{yr}^{-1}$ effect of tilting. Nevertheless these effects have a total uncertainty of $0.1 \mathrm{~mm} \mathrm{yr}^{-1}$, due to methodology limitations. The addition of lithospheric deformation to natural compaction yields a better adjustment to the DInSAR-measured subsidence with similar outliers (Fig. 3b). Considering the DInSAR and the methodological uncertainties, general subsidence rate of the Ebro delta plain is expected to range from $\sim 0$ to $\sim 2.3 \mathrm{~mm} \mathrm{yr}^{-1}$.

\section{Discussion}

As seen in the results, not all the measured points are coherent with the calculated subsidence. Some domains with low sediment thickness present higher subsidence rates than the average while other domains with high sediment thickness show aggradation. These domains are located on the main land and the coastal regions of the delta plain respectively. This data seems to contradict the Meckel et al. (2007) statement that compaction increase with thickness. This apparent contradiction can be explained through the composition of the soil. The inner Ebro delta plain contain sectors with abundant organic matter such as Ullals and Amposta, as can be seen on the soils map (Fig. 1)

Organic matter-rich dedposits are also found on the inner delta plain's (Maldonado, 1972). Presence of organic matter boosts compaction as it has an accelerated compaction capacity which can be up to $60 \%$ of its original volume. In addition the compaction rate is higher in recently deposited materials (Bos et al., 2012). On the contrary, sea side areas such as Platjola or Riumar domains are composed by sandy near saturated soils, where compaction occurs shortly after deposition and as consequence its residual compaction is low (Revil et al., 2002). In addition, due the low aggradation rate, Ebro delta coastline on selected sectors is in regression (Rodriguez Santalla, 2004). As a consequence the beach profile tend to rise its onshore section (Doyle et al., 2015). As the DInSAR signal is based on reflectivity coherence which does not change with the process, this onshore rise of beach sediment is detected as accretion.

In addition to the local processes affecting the subsidence phenomenon, DInSAR-based measures and the subsidence rate calculation approach have some limitations that should be considered. As a consequence of DInSAR corrections, stable measures (without movement) can show certain displacement. Consequently a stable filter should be applied. Barra et al. (2017) determine the limit of movement at the double of standard deviation, which in Ebro delta record imply a value of subsidence rate of $1.78 \mathrm{~mm}$. Consequently, average subsidence rates on most of the Ebro delta domains are within the DInSAR error range. Despite the local effects and methodological limitations, results are considered of good quality as the measured DInSAR data and the subsidence approach based on delta sediment compaction and lithospheric characteristics show a good agreement. This agreement occurs between DInSAR values over and under the stability limit as well as with the subsidence approach. Based on this match and considering that DInSAR measures and subsidence approach are independent, it can be stated that the obtained results of subsidence rate over Ebro delta plain are reliable.

\section{Conclusions}

Ebro Delta average subsidence, ranges from $<1$ to $\sim 2.3 \mathrm{~mm} \mathrm{yr}^{-1}$, being higher on the distal tip of the delta. The geological analysis of the contributing factors, suggests that subsidence is mainly driven by natural sediment compaction $(\sim 76 \%)$ followed by continental platform margin flexural effect $(\sim 13 \%)$ and tilting $(\sim 11 \%)$. Despite the general trend, the Ebro delta contain domains of accelerated subsidence, and domains with accretion, indicating strong influences of soil characteristics and environmental dynamics, specially sea level changes and its derived coastal erosion. 
Data availability. The processed data used in this work is proprietary of the government of Catalonia through the Institut Cartogràfic I Geologic de Catalunya (ICGC). In particular cases some of this data can be made available by ICGC under request. Queries may be addressed to ICGC mailbox https://www.icgc.cat/en/The-ICGC/ Contact/Contact-mailbox (last access: 19 February 2020). The DInSAR data used is property of the European Space Agency (ESA) which is publicly available through the ESA data portals for each earth observation mission in the following links (last access: 19 February 2020):

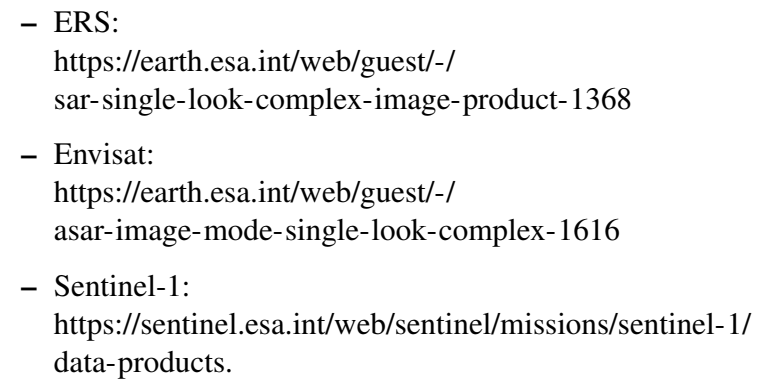

Author contributions. JM supervised the project. MV and RP compiled and analyzed the Subsidence sources and contributed to the interpretation of its results. OM and FP compiled and processed the DInSAR data, and contributed to the interpretation of its results. XR-LL analyzed the DInSAR data, the joint results, and took the lead in the writing the manuscript. All authors provided critical feedback and helped shape the research, analysis and manuscript, and read and agreed to the published version of the work.

Competing interests. The authors declare that they have no conflict of interest.

Special issue statement. This article is part of the special issue "TISOLS: the Tenth International Symposium On Land Subsidence - living with subsidence". It is a result of the Tenth International Symposium on Land Subsidence, Delft, the Netherlands, 17-21 May 2021.

Financial support. This research has been supported by the European Commission under the LIFE+ program (grant no. LIFE13 ENV/ES/001182).

\section{References}

Barra, A., Solari, L., Béjar-Pizarro, M., Monserrat, O., Bianchini, S., Herrera, G., Crosetto, M., Sarro, R., González-Alonso, E., Mateos, R., Ligüerzana, S., López, C., and Moretti, S.: A Methodology to Detect and Update Active Deformation Areas Based on Sentinel-1 SAR Images, Remote Sens., 9, 1002, https://doi.org/10.3390/rs9101002, 2017.

Benjumea, B., Gabàs, A., Macau, A., Bellmunt, F., Vilà, M., and Figueras, S.: Geophysical and Geological Studies for Subsidence
Assesment of the Ebro Delta, Project Ebro ADMICLIM, European Commission LIFE Programme: LIFE13 ENV/ES/001182, 2017.

Bos, I. J., Busschers, F. S., and Hoek, W. Z.: Organic-facies determination: a key for understanding facies distribution in the basal peat layer of the Holocene Rhine-Meuse delta, The Netherlands: Classification key for identifying organic-facies, Sedimentology, 59, 676-703, https://doi.org/10.1111/j.1365-3091.2011.01271.x, 2012.

Church, J. A. and White, N. J.: Sea-Level Rise from the Late 19th to the Early 21st Century, Surv. Geophys., 32, 585-602, https://doi.org/10.1007/s10712-011-9119-1, 2011.

Doyle, T., Chivoiu, B., and Enwright, N.: Sea-Level Rise Modeling Handbook: Resource Guide for Coastal Land Managers, Engineers, and Scientists, Professional Paper, USGS, 2015.

Fatorić, S. and Chelleri, L.: Vulnerability to the effects of climate change and adaptation: The case of the Spanish Ebro Delta, Ocean Coast. Manag., 60, 1-10, https://doi.org/10.1016/j.ocecoaman.2011.12.015, 2012.

Giosan, L., Syvitski, J., Constantinescu, S., and Day, J.: Climate change: protect the world's deltas, Nat. News, 516, 31-33, 2014.

Higgins, S. A.: Review: Advances in delta-subsidence research using satellite methods, Hydrogeol. J., 24, 587-600, https://doi.org/10.1007/s10040-015-1330-6, 2016.

Ibáñez, C., Canicio, A., Day, J. W., and Curcó, A.: Morphologic development, relative sea level rise and sustainable management of water and sediment in the Ebre Delta, Spain, J. Coast. Conserv., 3, 191-202, 1997.

Ibáñez, C., Day, J. W., and Reyes, E.: The response of deltas to sea-level rise: Natural mechanisms and management options to adapt to high-end scenarios, Ecol. Eng., 65, 122-130, https://doi.org/10.1016/j.ecoleng.2013.08.002, 2014.

Ibañez, C., Alcaraz, C., Caiola, N., Prado, P, Trobajo, R., Benito, X., Day, J. W., Reyes, E., and Syvitski, J. P. M.: Basin-scale land use impacts on world deltas: Human vs natural forcings, Glob. Planet. Change, 173, 24-32, 2019.

Jevrejeva, S., Moore, J. C., and Grinsted, A.: Sea level projections to $\mathrm{AD} 2500$ with a new generation of climate change scenarios, Glob. Planet. Change, 80-81, 14-20, https://doi.org/10.1016/j.gloplacha.2011.09.006, 2012.

Maldonado, A.: El delta del Ebro. Estudio sedimentológico y estratigráfico, $\mathrm{PhD}$ Thesis, Universitat de Barcelona, 1972.

Mauffrey, M.-A., Urgeles, R., Berné, S., and Canning, J.: Development of submarine canyons after the Mid-Pleistocene Transition on the Ebro margin, NW Mediterranean: The role of fluvial connections, Quat. Sci. Rev., 158, 77-93, https://doi.org/10.1016/j.quascirev.2017.01.006, 2017.

Meckel, T. A., Ten Brink, U. S., and Williams, S. J.: Sediment compaction rates and subsidence in deltaic plains: numerical constraints and stratigraphic influences, Basin Res., 19, 19-31, https://doi.org/10.1111/j.1365-2117.2006.00310.x, 2007.

Miller, K.: Sea level records, available at: ftp://ftp.ncdc.noaa. gov/pub/data/paleo/contributions_by_author/miller2005/ miller-sealev-originalcontrib.xls (last access: 19 February 2020), 2013.

Mora, O., Pérez, F., Marchán, J. F., Marturià, J., and Corbera, J.: Measures of Surface Movements in Catalonia using Sentinel-1 Data, The Ever Growing Use of Copernicus Across Europe'S Regions, European Commission (EC), 2018. 
Revil, A., Grauls, D., and Brévart, O.: Mechanical compaction of sand/clay mixtures, J. Geophys. Res.-Solid, 107, 2293, https://doi.org/10.1029/2001JB000318, 2002.

Rodriguez Santalla, I.: EUROSION Case Study Ebro Delta - Spain, Case study, Universidad Rey Juan Carlos, Amposta, Spain, available at: http://www.eurosion.org/shoreline/49ebrodelta.html (last access: 19 February 2020), 2004.

Rodriguez-Lloveras, X., Vilà, M., Pi, R., Mora, O., Pérez, F., and Marturia Alavedra, J.: Subsidence susceptibility of the Ebro delta Plain, Deliberable, ICGC, available at: http://www.lifeebroadmiclim.eu/wp-content/uploads/2019/ 08/B6_ZoningXofXsubsidenceXEbroXdelta.pdf (last access: 19 February 2020), 2018.
Siddall, M., Rohling, E. J., Almogi-Labin, A., Hemleben, C., Meischner, D., Schmelzer, I., and Smeed, D. A.: Sea-level fluctuations during the last glacial cycle, Nature, 423, 853-858, 2003.

Stanley, D. J. and Warne, A. G.: In this Month's issue: Holocene Sea-Level Change and Early Human Utilization of Deltas, GSA Today, 7, 1-7, 1997.

Syvitski, J. P. M., Kettner, A. J., Overeem, I., Hutton, E. W. H., Hannon, M. T., Brakenridge, G. R., Day, J., Vörösmarty, C., Saito, Y., Giosan, L., and Nicholls, R. J.: Sinking deltas due to human activities, Nat. Geosci., 2, 681-686, https://doi.org/10.1038/ngeo629, 2009. 